msh-mss Mathématiques et sciences humaines

141 | Printemps 1998

Varia

\title{
Droites discrètes et calendriers
}

Discrete straight lines and calendars

Albert Troesch

\section{OpenEdition}

Journals

Édition électronique

URL : http://journals.openedition.org/msh/2760

DOI : $10.4000 /$ msh. 2760

ISSN : $1950-682$

\section{Éditeur}

Centre d'analyse et de mathématique sociales de l'EHESS

\section{Édition imprimée}

Date de publication : 1 mars 1998

ISSN : 0987-6936

\section{Référence électronique}

Albert Troesch, « Droites discrètes et calendriers », Mathématiques et sciences humaines [En ligne], 141 | Printemps 1998, mis en ligne le 10 février 2006, consulté le 23 juillet 2020. URL : http:// journals.openedition.org/msh/2760; DOI : https://doi.org/10.4000/msh.2760

Ce document a été généré automatiquement le 23 juillet 2020.

(c) École des hautes études en sciences sociales 


\title{
Droites discrètes et calendriers
}

\author{
Discrete straight lines and calendars
}

Albert Troesch

\section{RÉSUMÉS}

La structure d'un calendrier peut être décrite par une suite de formes quasi-affines. Une telle suite, que j'appellerai base quasi-affine, généralise la notion de base de numération. Le problème de la conversion de dates est ainsi ramené à l'écriture du Jour Julien dans une telle base. Un algorithme de reconnaissance de droites discrètes permet d'obtenir la bonne base quasi-affine. A titre d'exemples sont traités les calendriers julien, grégorien, musulman et judaique.

The structure of a calendar can be described by a sequence of quasi-affine forms. Such a sequence, that will be called quasi-affine basis, generalizes the notion of numeration basis. The problem of the date conversion is therefore reduced to the writing of the Julian Day in such a basis. A discrete straight line recognizing algorithm enables us to obtain the good quasi-affine basis. As examples are given the julian, gregorian, islamic and judaic calendars.

\section{INDEX}

Thèmes : algorithmes - algorithmique, approximation, arithmétique - théorie des nombres 